\title{
Reviews of the book
}

Fintech is not the next 'big thing.' It is the big thing now! Fintech is the new business model for the global financial sector, offering clear and enormous potential for vast economies of scale and scope, massive cost savings and efficiency gains, significant risk reduction, and opening the door to banking for literally billions of currently unbanked people. Professor Fischer has done a masterful job of expertly and informatively taking us through all aspects of the revolutionary new fintech business models. Using state-of-the-art research techniques, he insightfully shows us how fintech firms are financed and how they aspire to create value. His in-depth case studies unlock the keys to success in the fintech sector. His fascinating book is a 'must read' for all financial professionals.

Professor Dr. Stephen Morrell, Professor of Economics and Finance, Andreas School of Business, Barry University, Miami, USA

Matthias Fischer's latest book offers a comprehensive overview of fintech business models around the world. With a very pedagogical approach, and in a particularly fluid style, the author takes us into the strategic logics of these new entrants to finance, who are carriers of innovation and sometimes of disruption, and whose strategies are focused on the need to always meet the emerging expectations of their customers. This precise and well-documented analysis should enable banks to reposition themselves in their ecosystem by studying these new business models, which will enable them to boost their growth.

Professor Dr. Nadine Tournois, Dean of IAE Nice Graduate School of Management, Université Côte d'Azur, France, Chevalier de la Légion d'honneur

Fintech Business Models is a must-have book to understand the rapid and intense changes occurring in the financial sector. New technologies have allowed the birth of new financial species, such as fintech, more adapted to the new digital economy. The content dedicated to the application of blockchain technology helps to understand its opportunities in the financial sector, not only in the means of payment and cryptoactives, but also in how blockchain can make multiple internal processes improve, allowing to optimize the management, efficiency and even security of operations. Without any doubt, this book offers an extraordinary vision of how the fintech sector has become a catalyst for change in banking in the context of the current Digital Society.

Phd. Ricardo Palomo, Full Professor of Finance, Deputy Chancellor for Digital Transformation at Universidad CEU San Pablo, Madrid, Spain and member of the Board of Alastria Blockchain Ecosytem

This book provides a detailed and original overview of the most important fintech business models in the major global markets. Through a savvy use of the well-known 
Business Model Canvas methodology, the author explores the unique ecosystem, business model's components, and sources of competitive advantage of successful fintech firms. The book, in particular, offers an insightful and comprehensive analysis of the winning and losing strategies and performances of fintech firms by segment of activity such as, instant digital payments, crowd-funding, robo-advisory, alternative finance, credit \& factoring, social trading, personal finance management, blockchain and cryptocurrencies. It is indeed a very unique and valuable study on the fintech industry, its trends, and its emerging business models.

Prof. Dr. Ivo Pezzuto, The International School of Management, Paris, France and Adjunct Professor of International Business and Strategic Management Università Cattolica del Sacro Cuore, Department of Business Management, Milan, Italy

The emergence of fintechs is one of the most relevant drivers of change in the financial services industry. The book presented here delivers an impressing overview of fintechs' activity areas, business models and funding patterns. The book reflects the state of the art of the current fintech world.

Prof. Dr. Jürgen Moormann, Professor of Bank and Process Management at Frankfurt School of Finance \& Management, Germany 



\section{Matthias Fischer}

\section{Fintech Business Models}

Applied Canvas Method and Analysis of Venture Capital Rounds

\section{DE GRUYTER}


ISBN 978-3-11-070450-1

e-ISBN (PDF) 978-3-11-070490-7

e-ISBN (EPUB) 978-3-11-070493-8

Library of Congress Control Number: 2020946366

Bibliographic information published by the Deutsche Nationalbibliothek The Deutsche Nationalbibliothek lists this publication in the Deutsche Nationalbibliografie; detailed bibliographic data are available on the Internet at http://dnb.dnb.de.

(c) 2021 Walter de Gruyter GmbH, Berlin/Boston Cover image: olaser/E+/Getty Images Typesetting: Integra Software Services Pvt. Ltd. Printing and binding: $\mathrm{CPI}$ books $\mathrm{GmbH}$, Leck

www.degruyter.com 